\title{
Perspectives of Working Children on their Education and Life Goals: A Case Study
}

\author{
* Gouhar Pirzada \\ ** Yaar Muhammad (Corresponding Author) \\ $* * *$ Faisal Anis
}

\begin{abstract}
Despite several interventions from the public, private and NGO sectors, the sustainability of education for working children has always been a challenge in Pakistan. Setting life goals is the first step towards achieving them, and setting life goals itself is a life skill, not possessed by everyone. Children who possess this valuable skill tend to perform better in managing their careers, time, and life. A framework proposed by Cassandra Massey quite explicitly explains the various factors that working children need to consider and focus on while pursuing their life goals. It comprises eight attributes, including Self-care, Relationships, Money, Personal development, Home-life, Community, Passions, and Work-life. It is essential to know-how and to what extent these attributes affect the education and life goals of working children to understand their perspectives. The multiple case study research design was used in this study to illustrate the issue and getting similar and contrasting patterns from responses of the five cases. Findings from all five case studies that there exists a high determination and commitment towards education, and 4 out of 5 cases expressed there are high chances for them to be able to achieve their life goals. Based on findings various implications are discussed.
\end{abstract}

Keywords: Working children, Education, Life goals, Work-life, Passion.

\section{Introduction}

Despite the issue of child labor being catching worldwide attention in recent times, developing countries, including Pakistan, seem to get most affected by the phenomena. The issue remains an ever-rising menace with direct and extended numerous associated problems. The exact number of working children across the globe is still unknown, and several figures have been suggested by various organizations. However, there seems to an agreement on the rapid increase of working children all over the world in recent years.

Children working for earning are one of the effects of low illiteracy and a high poverty rate in Pakistan. There are almost 23 million children out of school, whereas the number hits 9 million in Punjab province alone, which is supposedly the largest and most developed province of the country (UNICEF, 2020). The number of working children has approximately reached 1.2 million in Lahore, the capital city of Punjab (GoP, 2016). A large number of these children are working in places like automobile workshops, tea stalls (dhabaas), hair salons, brick kilns, weaving industry, power looms and small size factories, trash pickers, and domestic workers in Pakistan. They are called 'Chotey' (the younger one), but many of them are the breadwinning productive sons in their families. Begging is also one form of labor, which engages children to beg on assigned locations to make money for their masters. Despite the civil society's hue and cry, leading to some legislative measures and several governments' efforts in recent years to curb this evil, the massive number of working children is still on a constant rise. Like most developing countries, it is a major and noteworthy challenge for Pakistan to bring these children back into schools and retain their livelihood.

Raja (1983) presented his findings from his study that comprised of 50 children to illustrate the socio-economic background of working children. He found that the average working hours of $70 \%$ of working children vary between 9 to 10 hours every day and more than $75 \%$ of these children have illiterate parents. In another study, Khan (1982) conducted a survey of 100 working children from three prominent industrial cities of Punjab (Lahore, Gujranwala, and Sialkot) and found that poverty, family tradition, fight for survival, and not having any other choice to be the main reasons for these

* University of Management and Technology, Lahore Email: gouhar.pirzada@step.edu.pk

** University of Management and Technology, Lahore Email: edyaar2008@ yahoo.com

*** University of Management and Technology, Lahore Email: faisal.anis@umt.edu.pk 
children to work. It was also found that 11 years was the average age of those working children. Khan (1982) analyzed the relationships existing between economic growth, poverty, and child labor and his findings portray the extra tougher circumstances that working children have to go through to earn lesser money than adults for the extra hard work and laborious working hours which are too long in comparison to adults.

It is important to know the perspectives of these working children about their education and life goals. It is generally thought that the pursuit of education for working children becomes more challenging since these children are consumed in the tough life of earning bread or contributing to run their families. Earning at a younger age may fascinate some to focus more on the jobs instead of seriously considering their life goals and education.

It is believed that setting life goals is the first step towards achieving them, and setting life goals itself is a life skill not possessed by everyone. Goals are "desired states that people seek to obtain, maintain, or avoid" (Emmons, 1996, p. 314). "Through them, people give direction to development; through effective goal-directed actions, they shape their life course in aspired directions. Children who possess this valuable skill tend to perform better in managing their careers, time, and life. Not only are they likely to focus more on what they want and less on what they don't want in their lives, but they also learn to plan, prioritize, and execute to get favorable outcomes. It also develops their ability to persist, and whether they achieve the goal or not, they learn to accept full responsibility for what they choose to do. Setting life goals also helps in creating and rebuilding confidence, enhances self-esteem, and leads to the attainment of a sense of satisfaction. It creates challenges to overcome and opportunities to learn and grow by pursuing them. Specifically, during the times of adolescence and adulthood, one vital decision an individual takes is setting and pursuing life goals.

Ryan and Deci (2009) explained the concept of self-determination theory (SDT), which is an analysis of an individual's motivation that requires a full understanding of one's innate psychological needs for competence, capabilities, control, and relatedness. Similar to the other existing need theories, the SDT also stresses the socio-economic context of individuals for their psychological development and well-being. "Social contexts and individual differences that support satisfaction of the basic needs facilitate natural growth processes including intrinsically motivated behavior and integration of extrinsic motivations, whereas those that forestall autonomy, competence, or relatedness are associated with poorer motivation, performance, and well-being" (Deci \& Ryan, 2000, p. 227).

The framework proposed by Cassandra Massey quite explicitly explains the various factors that individuals need to consider and focus on while pursuing their life goals (Massey, 2020). Being a certified practitioner, she argues in favor of the model exclusively for working women. It is interesting to apply the same attributes for assessing working children's perspectives about their life goals. This framework comprises eight attributes, including Self-care, Relationships, Money, Personal development, Home-life, Community, Passions, and Work-life (Massey, 2020).

This research paper concentrates on five case studies of working children collected by authors. Each of the outlined cases has been given a pseudonym and respective demographic description in the beginning. Cassandra Massey's framework has been applied to draft the interview guides for participating in working children, followed by interactions and interviews of their parents or guardians as well as their teachers. Semi-structured interview questions were preferred to probe maximum data. 


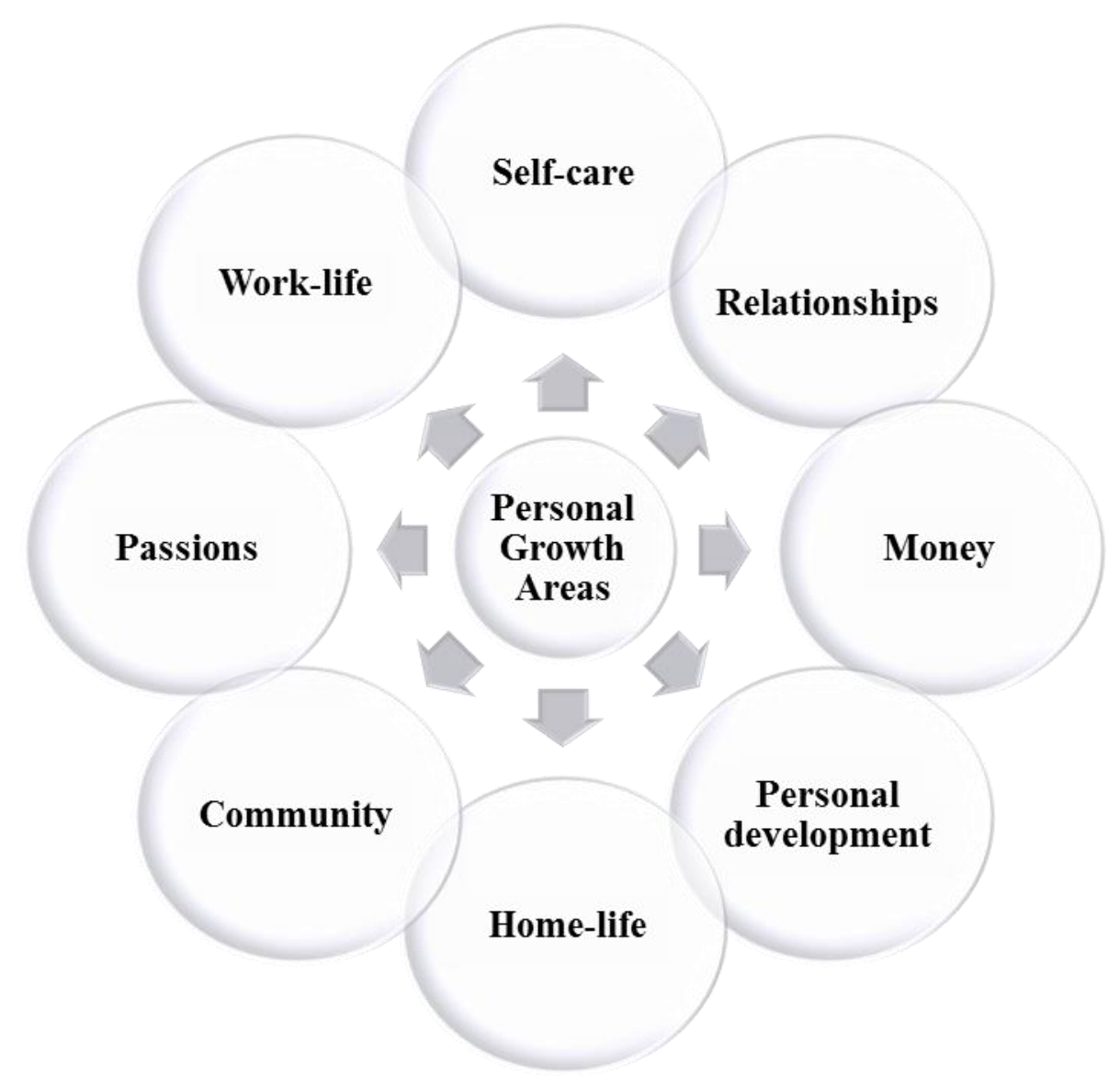

Figure 1: Personal Growth Areas Framework proposed by (Massey, 2020).

\section{Methods and Materials}

The paper is written using qualitative inquiry and case study research design. The case study research involves the study of a case within the real-life, contemporary context or setting (Cohen, Manion, \& Morrison, 2018; Yin, 2018). According to Creswell (2007), case study research is a strategy of inquiry in which the researcher explores in depth a program, event, activity, process, or one or more individuals. This study was also focused on developing an in-depth description and analysis of multiple cases of working children. Social Constructivism served as the research paradigm for this study since the researchers closely focused on understanding the world of participants through their perspectives and interpretation, with the acknowledgment that participants' backgrounds enabled in shaping their interpretations (Creswell \& Poth, 2018). It helped in the development of multiple meanings for attributes contributing to life goals and careers that the five cases associated with while sharing their opinions during interactions.

The case study approach is generally a popular choice of researchers who are inquiring in the education sector. It is used in this study to explore and highlight the issue of working children in their contexts in a time of nearly four weeks. The context of participants becomes more important to explore perspectives of five participants taken as case studies, making it a 'Multiple Case Study' research with a single site chosen, i.e., a private and exclusive charity school for working children, situated in Gulberg area of Lahore. Classes are held only on Sundays between 9 a.m. till 5 p.m., and it is $100 \%$ free education for these children. Books, uniforms, bags, and food are provided by the school. The Multiple case study - "a special effort to examine something having lots of cases, parts, or members" (Stake, 2013, p. vi) — was used in this study to illustrate the issue broadly and getting similar and contrasting patterns from responses of the five cases (Stake, 2013). A purposive sampling technique (Patton, 2015) has been employed to choose participants who are working children and attending this school. The framework by Cassandra Massey is utilized to formulate the selfconstructed interview guide. This deductive research route has enabled authors to comprehensively explore each case study on the eight attributes of this framework. 
The interview guide for the five participants was mainly comprised of 20 open-ended questions with a lot of potential for further probing. Questions were drafted to gain maximum information from participants' perceptions, beliefs, and behavior, all centric to the research aim to explore working children's perspectives about their education and life goals. Face-to-face semistructured interviews were conducted with all five participants who were initially approached through their teacher after getting consent from their parents. A flyer was designed initially to recruit participants, and the teacher's announcement in class helped in the final recruitment process. The duration of interviews varied with an average time duration of approximately 30 minutes. Interviews were recorded, followed by verbatim transcriptions to ensure nothing is missed while documenting all responses. Although these face to face interviews with participants formed major grounds for data collection and analysis, yet the academic progress of all participants was also seen in the students' progress documents. Besides, teachers' and parents' observations and commentaries were also used to triangulate the interview findings and to produce more robust results. Participants' quotations have also been used as a data display for each case study. Qualitative content and thematic analysis are done as the data analysis method. Pseudonyms were given to each participant to hide their real identity and ensure confidentiality and anonymity (Shaw, Howe, Beazer, \& Carr, 2019; Wiles, 2012).

\section{Findings}

\section{Case study 1: ASAD}

Demographic profile: 12 years old Muslim Punjabi male (studies at a charity school for working children in grade 5), works in a shoe factory.

Asad lives in a downtown area with his parents, three brothers, an uncle, and one cousin. He starts his day, usually at 10 a.m., eats breakfast, and occasionally watches television before going to work. His interaction with other family members is limited in the mornings. On Sundays, after school, he loves playing Cricket, Ludo, and Carem board with his brothers.

Asad works in a shoe factory in Majirabad, quite close to his home, and normally reaches the factory in 5 minutes. Sometimes, he starts the day at 8 a.m. and gets free at $8 \mathrm{p} . \mathrm{m}$. If there is less work, then he reaches around midnight and gets free around 10:30-11 p.m. On average, he works for 11 hours every day. His major job assignments include preparing leather sheets for shoes according to shoe sizes and making shoe soles.

Asad is passionate about becoming an engineer. He recalls his early childhood memories to share his father's dream of him becoming an engineer. He is extremely hopeful to live his father's dream one day.

At the job, whatever he knows is because of his master, 'Ustaad.' He credits his Ustaad for teaching him everything very comprehensively. His Ustaad performs the task himself and makes him observe it closely before Asad attempts the task on his own. Asad believes he is a quick learner, and it only took three months for him to learn all his major roles.

Although Asad views himself as a responsible worker who can take good care of himself, yet the works that he does, is sometimes tiring and painful. Once he injured his hand with a hammer, and nobody was around. He took the bandage from the first aid box in the factory and wrapped it around his hand, the mark of which is still visible on his left hand.

His family is living near the Chappar Stop area for almost eight years, and he likes the area and community. He finds the place reasonable only if his street is carpeted and the road is properly constructed.

Asad earns PKR. Five hundred per week, and he is daily offered food. He is proud of himself for being a good son who contributes to his family's income. House rent for the last two months is still not paid despite maximum efforts by all four earning hands of the family.

Asad believes himself to be a social person. He has 3-4 close friends who live near his home, and all of them were his class fellows in his previous regular school.

Asad wants to be an engineer in life. Despite all odds and hardships of working life, he firmly believes he can become an engineer even when he currently works full time and studies only on one day of the week. His ambition to achieve his life goal is determined enough to fight all obstacles. He intends to compensate for the time that he consumes in working full time by covering two standards in one year, which is possible at his school. He plans to start saving very soon for his studies after Matriculations. He feels pride in financially helping his parents and seems to love the skill that his job offers. After he became skillful in his job, his employer terminated one full-time adult to get the same 
amount of work done from Asad at comparatively very less cost. He still loves his work and the environment. His teacher puts him in the 'A grade category,' which is evident through his class tasks and assignments. His excellent numeracy skills support his career choices to become an engineer. Life is hard for Asad, but he seems to bravely accept the challenges and keeps the plan in mind.

\section{Case study 2: NAQASH}

Demographic profile: 14 years old Christian Punjabi male (studies at a private school for working children in grade 5), works in a men's hair salon.

Naqash lives near the Firdous market in a small home that he shares with 12 people, including his parents, three brothers, and maternal grandparents. He helps his parents in domestic chores every morning before going to work, which includes cleaning the house, washing dishes, buying groceries, and changing the clothes of his younger brother.

Naqash works in a men's hair salon. His job is to clean the floor of the entire salon and main entrance, along with dusting the furniture. These are all additional tasks that he performs being the 'Chota' (younger one) at solon. He reaches work at around midnight and usually gets free between 2 to 3 a.m., depending upon the customer flow. The other daily tasks include providing scissors, neck rolls, razors, shaving foams, and other materials to his Ustaad when he is serving clients. It has been a year since Naqash is working in the salon, and he feels it's good for him to learn this skill. Besides, it is only 10 minutes' walk from his home.

Naqash's love for firearms has greatly motivated him to join the Pakistan Army. He knows the journey is not an easy one, yet he believes it's attainable.

He learned hair cutting and shaving during his current job. He credits his Ustaad for teaching him everything related to the hair salon business; however, he keeps on learning new ways of hair coloring from the YouTube tutorials at the salon. Initially, he didn't like it, but his parents' desire made him go to work every day. Eventually, he started liking the job because he thinks he is getting skillful. At the moment, Naqash seems to be double-minded about joining the Pakistan army or have a salon of his own as his career goal.

Naqash works in a salon, and his usual tasks at the job involve accessories and tools like scissors, haircutting, and shaving machines, and blades. Minor cuts from blades on hand fingers are considered a trivial thing at a shop. His Ustaad taught him to apply basic safety rules while using the tools. Naqash's parents have also been very protective of him since he suffered from kidney disease for three years. He is still required to drink plenty of water throughout the day, which he forgets mostly because of the hectic routine.

He seems to quite like his community both at home and at work. He is fond of everyone in his street and enjoys playing Cricket sometimes. He wants a better market or superstore for his community to buy food items, chocolates, and popcorn, etc.

The young boy earns PKR 200 daily and an additional PKR 2000 at the end of the month. Tips from customers are the icing on the cake. Running a large household requires everyone to pitch in, he thinks. One reason for his desire to earn more is his mother. He doesn't like his mother to work. He said, "I work hard to earn more so that one day I can ask my mom to quit working."

Naqash considers himself to be highly sociable. He has nearly a dozen numbers of good friends, most of whom live in his street, and two friends at work who are his age.

Joining the Pakistan Army has always been a dream for Naqash. He believes he is born to become a soldier. Leaving studies and working full time was never on his mind until one day when he found his parents overwhelmed with the financial crises, which was a result of the cost of Naqash's kidney treatment. He has still not given up completely on his dreams and life goals. He cherishes his regular full-time schooling, yet he is confident of becoming a more useful member of his family through his current job. He believes he is making the best of his time by learning and earning, both at one time. He thinks he has not compromised on his Army related career goal, but he has only changed the path. He wows to continue studying on Sundays and, at the same time, wants to have his salon, one day, which he wants to name after his parents. The only thing he misses a lot is ample time to play with his cousins and friends. His teacher puts him in the category of "B" grade students and considers him a highly energetic person and life of all extra-curricular activities at school.

\section{Case study 3: HAMZA}

Demographic profile: 12 years old Punjabi Muslim male (studies at a private school for working children in grade 3), works in a motorcycle workshop. 
Hamza lives with nine other people in the tiny two rooms' quarters, including his grandparents, one maternal uncle, auntie, and their only daughter. He shares the room with his mother and three brothers. His father died 1.5 years ago. He works six days a week and spends Sundays in the special school for working children. He badly misses the absence of fun in his life. The only entertainment is half an hour that he spares in playing games on his mother's mobile before going to bed. He gets up at 7 in the morning, has breakfast with his brothers, and rushes towards the job. Occasionally, on Sundays after his school, he plays Cricket in the street with other boys from the neighborhood. He usually reaches the workshop at 8 a.m., but sometimes, he gets late, although the workshop is not too far from his home in Model colony Bazar. He works for almost 13 hours every day and gets back home between 9-9:30 p.m. Main tasks at the workshop he performs include disassembling flat tires from the frame of motorbikes, disassembling seats, repairing the backlight and front light of motorbikes.

Hamza seems a little sad for not regularly studying. His long tiring job has dimmed his chances of fulfilling his dream of joining the Armed forces. He doesn't seem to have a choice but to work. Life has been hard on him since the demise of his father. He still remembers the good days when he would not have to work and only had to go to school. However, he now thinks he should focus on his work and learn all skills. He wishes to have his workshop one day, where he will be the Ustaad.

Everything that Hamza knows about the motorcycle workshop (including the nut, bolt, and tools) has been taught to him by his Ustaad. He likes the way his Ustaad teaches him by practically demonstrating the task and verbally telling him details too. He likes his current job the most as it is enabling him to learn technical skills.

Hamza's work is risky, and workers at the workshop often get hurt. His fingers get scratches at least twice a week, and the usual hand bandages are used when required. His Ustaad provides bandages and also teaches everyone to consider safety precautions while working. His Ustaad does not also let him do very heavy work or use a hammer.

He lives in the Model Colony area, which is a highly populous downtown area. He quite likes the area and feels they have good neighbors. He thinks people are friendly and take care of each other, and most neighborhood kids are his friends.

Hamza earns PKR 50 daily for working and another PKR 50 as lunch allowance. After the death of his father, three brothers, including Hamza, started working; his elder brother works at a barbershop, his second elder brother goes to Madrassa to become a 'Qari' (a reader of Holy Quran), he works in the workshop, and their mother works as a house-maid. He does not know the exact household expense and income, and he only seems to know he must work like his two elder brothers.

Hamza believes he is a friendly person and gets along with his age fellows quite easily. He has seven friends who live in his street. At home, his grandparents are his favorite people as they take good care of him and tell him stories whenever he is free.

Hamza is a hardworking child who is making all efforts to contribute to running their household. He misses his father and recalls all the good times when his father would take all his siblings to parks on Sundays, and he would just study. Life after his father's death has been tough. Although he likes to attend Sunday school, he feels it is not enough for him. While discussing if working children can achieve their life goals, Hamza said, "Maybe some working children achieve what they want, but not everyone can work that long and study too." His performance in school has compromised too. His teacher puts him in the 'C' grade category. Comparing to other subjects, Hamza loves to draw, and his drawings usually have a male figure representing his late father. His mother feels he has gone stubborn after he left the regular school, and there are some mornings when he does not want to leave the bed. She has to forcefully send him to work. Despite all the tough lessons that life has taught him, he still wants to continue his education, although he seems to have little hope to join the Army with his current job type and long working hours.

\section{Case study 4: SAIMA}

Demographic profile: 12 years old Muslim Punjabi female (studies at a private school for working children in grade 5), works as a baby sitter and a domestic worker.

Saima has three sisters and two brothers and her parents in the family. Her elder sister works for a family and stays 24 hours there as a permanent maid. Her father is a security guard at a company, and her mother works as a cleaner for a rich family. She gets up at 5 a.m. and helps her 
younger sister and brother to get ready for school. Once they are gone, she sleeps again to wake up after an hour for cleaning the dishes and then goes to work. She gets a break at 1 p.m. to come back home to feed her younger brother, who is only four years old. After giving him lunch and putting him to sleep, she goes back to work again.

Saima works as a baby sitter for a family in Falcon colony, which she believes is a posh area of the city. She usually starts working from 9 a.m. until 1 p.m. She goes back again and works until 5 p.m. Her main job is to babysit a 2.5 years old child, preparing milk and feeder for the baby, putting the baby to sleep, and once the baby sleeps, Saima cleans the baby's room and tidies up his clothes and wardrobe.

Telling about her life goals, Saima said, "When we were little kids, my mother used to tell me that she wishes for me to become a doctor. I heard her saying it all the time so much that I made it my dream to become a doctor one day." She seems determined about it and believes she will work hard and study more to achieve her goals.

She does not find her job hard as she believes she is already trained in these tasks because she has been managing her younger siblings as her mother has always been working since the times, she was very young. Although her job requirements are easier, Saima wants to switch to another job where she could earn more and contribute more to her family's gross income. Her long-term career goal is to become a doctor and help people who are sick.

Saima has been sick in her early childhood. She suffered from heart disease and underwent surgery. She used to have blood vomits too, and the thought of this often terrifies her even now.

Speaking about the community she lives in, she seems frustrated with the mud and water that is pooled whenever it rains because there is no proper sewerage system. Their house rent is very high, in her opinion, considering its very small size. She remembers her times of living in the village couple of years ago before the family migrated to Lahore, and she seems to miss her village life.

Saima earns about PKR 5000 for a month from her babysitting job, which is collected by her mother from her house lady on the $5^{\text {th }}$ of every month. Her father earns around PKR 15,000, and she believes running the whole household, paying their house rent and utilities are not possible if they rely only on his father's salary.

She seems quite a reserved person and does not open up with everyone. She only has one friend who is her cousin, as well as her class fellow at school.

Saima is a quiet young girl who is brave enough to help her family to settle in Lahore. She adores her elder sister, who lives away from home to work as a domestic worker. In Saima's view, her elder sister is sacrificing for the whole family, and she tries to follow in her footsteps by working and earning for her family. Her parents' decision to leave the village and migrate for an urban life has its toll on her. She seems to miss her friends, school, teachers, and neighbors back in her village. She considers the life of working children to be tough and hard to achieve their career goals while working full time. Academically, she is an average performer. Her teacher marks her in the " $\mathrm{C}$ " grade category. She seems to struggle with Mathematics and English, yet her ambition to become a doctor remains high. In her own words, "Life is too unpredictable, but I will try my level best to fulfill my mother's wish to become a doctor."

\section{Case study 5: SARAH}

Demographic profile: 11 years old Muslim Punjabi female (studies at a private school for working children in grade 5), a domestic worker.

Sarah lives with her mother, two sisters, and one brother. Her father died a few years ago. Her day starts at 7 a.m. with the regular domestic chores, including house cleaning, dishwashing, and preparing breakfast with her mother for her siblings before she leaves for work at 11 a.m. She works for approximately 6.5 hours and gets back home, usually before 6 p.m. She continues to work at home and ensures everything is good before her mother comes back from her job, usually by 8 p.m.

Sarah works as a house-maid in a home, which is not too far from her place, and it takes 5 minutes for her to reach her workplace. Her major job tasks include dishwashing and babysitting for the three kids.

Sarah wants to be a teacher and idealize her school teacher back in the village where they used to live before shifting to Lahore. Her village school teacher still has a strong influence on her. She still remembers the ways her teacher would use to encourage everyone in the class for active 
participation. In her view, she tries to copy her teacher in every possible manner, and she seems very confident about achieving it too.

Sarah credits her house lady for whom she works. The lady taught her new ways of dusting and cleaning with several sprays, lemon, and old newspapers and also about taking very good care of her babies and making milk feeders for them.

Although she seems to like her employer's family and she is quite attached to the kids too, she feels she is underpaid, and as soon as she finds a better opportunity, she will switch her job. "Whoever pays more would be my first choice, because to me working is earning. I would accept any new job if it pays more than this job," said Sarah. Her dream of becoming a teacher keeps her spirits high to concentrate on her studies. She loves reading storybooks before sleeping every night.

Sarah thinks she is now fully trained to take up an even challenging job after taking care of three kids at one time. She never faced any issue related to her self-care. While playing with kids, she acts like a horse for them, and the kids enjoy this. Doing so for a long time sometimes hurt her knees, but she feels happy when kids are cheerful.

She lives in a dense street behind the industrial area. Lack of clean drinking water is a usual problem for every household in the vicinity. Comparing her times in the village, she thinks living in a bigger city is fascinating yet very difficult. Sometimes she feels to be imprisoned in Lahore.

Sarah earns PKR 4500 for a month, and she works six days a week. She feels she has to earn more to further support her family.

Sarah seems to be an introverted person. She thinks a lot but speaks less. Being a reserved girl, she hardly has any friends. She is very attached to her mother and tries her best to comfort her by sharing maximum house chores with her.

Sarah appears to be a quiet child with a lot of noise in her mind. At such a young age, she seems to have trouble with two major incidences in her life. Her family's decision to migrate from the village and shift to Lahore became her first trauma, and her father's death was another bad patch in her life. She seems to keep herself busy all the time and remains a hardworking student at school, yet she does not like to socialize a lot. Based on her classroom performance and commitment to education, her teacher considers her a "B+" category student, and she thinks, with little more effort and concentration, Sarah could easily improve her grades. Sarah feels the attainment of life goals for working children is tough since there are no holidays for them. Every day is a working day for them. Financial issues take their focus away from education. She shared her thoughts: "Throughout the month, I wait for my pay, and the best day of the month is when I get my salary."

\section{Discussions and Conclusion}

The research explores working children's perspectives about their education and life goals. It is evident from all five case studies that there exist a high determination and commitment towards education. 4 out of 5 cases expressed there are high chances for them to be able to achieve their life goals. Only one case (Hamza) showed pessimism about it; nevertheless, all cases reflected positively about the importance of education and continuous schooling for them.

The observations and views of teachers further affirm the notion that working children are enthusiastic and committed towards both education and their life goals. While sharing her experience of differentiating the regular school children from working children, one of the teachers suggested working children to be far more serious about their careers. She mentioned, "Comparing to the regular ones, working children are more passionate about becoming what they always want to become in life. The level of carefulness and determination is higher in comparison to their counterparts. Their major deficiency is lack of time for studies. Their lives make them physically strong and emotionally mature." She quoted several examples in favor of her argument. She also believed that there is a need to customize the curriculum for working children since they only have one day to study; the teaching methodologies have to be very carefully selected. There is a dire need to focus more on educating them further on their Self-care and safety precautions. Both teachers showed resentment about the weaker sense of self-care these children have. Most of them come with injuries and bandages on their fingers, which is due to the excessive amount of work they do without following adequate safety procedures.

The role of Ustaad is of primary significance for all case studies. It is the Ustaad who teaches everything on the job. A good Ustaad takes good care of these children. Good practices include some training methods of learning by doing, feeding children on the job, and relaxation in case they get 
sick. However, in most cases underpaying working children and too long working hours steal the element of fun and joy from their lives.

The case studies also reveal several root causes and factors contributing to the phenomena. Poverty remains on top of the list. Pakistan, like several other developing countries of South Asia, is fighting against poverty, and with a rapid increase in population, the stance against poverty further weakens. Poverty acts as a catalyst in changing parents' perceptions about the life goals and education of their children. Most people view it as a question of survival. They look for a better paymaster for their children instead of good schools. Each child becomes an extra source of income for families of working children. Pasha, Iqbal, and Farooq (2001) state, "Lack of awareness and illiteracy are the major causes among parents who avoid sending their kids to schools. It has been observed that $61.31 \%$ of the working children are from illiterate families" (p. 4).

Unplanned migrations to urban cities are another factor that highly contributes to more children getting out of schools and start earning. Families find it hard to coup up with the financial pressures of living in bigger cities, resulting in adding as much income to every family member as possible. Less economic opportunities drive people to move to bigger cities. Food, clothing, and shelter as primary needs are fulfilled if every child starts working, and any income that they bring home is an additional charm for the financially struggling parents.

Employers also benefit a good deal when it comes to hiring a child. In the majority of cases, working children feel they are underpaid. They work for extra longer shifts with 11 hours on average and are compensated very little in comparison to the adult workforce. Lack of policymaking and very fragile implementation of laws relating to working children further encourage employers, especially in the informal sector, to continue the practice.

School dropouts, because of the hostile school environment and aggressive teachers' behavior, also sometimes result in the child being a rebel to education. Instead, they find it more worthy of starting earning.

Findings from the interviews of all five cases present interesting patterns reflecting the Life goals framework by Massey (2020). Factors of "Passion" and "Personal Development" seem to be the strongest ones that support working children in pursuing their education life goals. While "Self-care" remains a challenge for the majority of cases, the role of "Community" and "Relationships" remain low key factors despite their high potential impact. The imbalance between "Work-life" and "Homelife" depicts a major challenge, and "Money" remains the biggest issue that hinders all cases to focus more on working and earning instead of pursuing education and life goals; however, most cases seem to strive on both fronts in their lives.

In most cases, working children have tight schedules and very less leisure time. Extracurricular activities could greatly help to teach them in a relaxing environment.

The issue of working children is critical for Pakistan, being the fifth most populous country and representing the massive number of children. Future research on the subject should establish what needs to be further done in addressing the issue. It is vitally significant to study if working children can attain their life goals and the nature of obstacles they face in their adult lives. The potential longterm impact of such research studies also results in better awareness of the community at large and specific stakeholders, including policymakers and governing institutions. It is also important to study the perspectives of working children's employers in any future research.

There is no doubt that working children are equally motivated and determined to achieve their life goals. Despite all the hardships and problems, the vast majority of these children dream and hope for a better life. With every working day, their tendency to bear these hardships strengthens them physically. What is essentially required is to ensure they do not lose this hope. The higher need for more special schools for these children is un-precedent than at any time in the past. This is particularly important when the constitution of the Islamic Republic of Pakistan's Article 25 A delineates that "the State shall provide free and compulsory education to all children of the age of five to sixteen years in such manner as may be determined by law" (NA, 2018, p. 15).

Although this research study helps in understanding perspectives of working children about their life goals and education, yet there requires a further investigation of what needs to be done to further support them in their pursuit of successful careers. Further research into the current and required modification in the curriculum and teaching methodologies could add substantial value to the subject. The need to study on-job learning and training opportunities also remains salient important. 
The current study lacks interaction with the employers of working children, which can also provide further insight into the phenomena.

This research study positions various elements of the framework proposed by Massey (2020) as per their influence and ability to enable working children to achieve their career goals; however, further research to initiate the study and link between all these elements could potentially reveal foundations for the required actions. It will be interesting to add public sector teaching initiatives for working children as well as multiple locations and other cities too.

\section{Recommendations}

Based on the findings from the five face-to-face interviews with all cases, brief interactions with their parents and guardians, and two interviews with their teachers, the following recommendations for policy and practice are also stated:

(1) Basic safety and self-care education should be provided at schools that are catering to working children's education.

(2) Counseling sessions should be arranged for parents who migrate to urban cities like Lahore, and they put their children's education at stake to manage financial pressures.

(3) Skill-based education for working children should be advocated since they are already working, and their minds tend to learn practical things more quickly in the form of hands-on training format.

(4) It is observed from the five case studies that the work hours for these children are enormously higher, which tires them physically and psychologically. Working hours should be reduced, and there needs a state policy on it that must be exercised in true spirits.

(5) Regular parent-teacher meetings are highly favorable to avoid dropouts of working children. In the majority of cases, parents compel children to quit schools, whereas in some cases, parents can greatly help in sending demotivated children back to school.

(6) Regular career counseling and motivation sessions should be arranged by schools for working children since they are fighting on many fronts, and these sessions will help in sustaining their interests and focus on career goals.

\section{References}

Cohen, L., Manion, L., \& Morrison, K. (2018). Research methods in education (8th ed.). New York, NY: Routledge.

Creswell, J. W. (2007). Qualitative inquiry \& research design: Choosing among the five approaches (2nd ed.). Thousand Oaks, CA: Sage.

Creswell, J. W., \& Poth, C. N. (2018). Qualitative inquiry and research design: Choosing among five approaches (4th ed.). London: Sage publications.

Deci, E. L., \& Ryan, R. M. (2000). The" what" and" why" of goal pursuits: Human needs and the selfdetermination of behavior. Psychological Inquiry, 11(4), 227-268.

Emmons, R. A. (1996). Striving and feeling: Personal goals and subjective well-being. (p. 313-337). . In P. M. Gollwitzer \& J. A. Bargh (Eds.), The psychology of action: Linking cognition and motivation to behavior (pp. 313-337). New York: The Guilford Press.

GoP. (2016). Pakistan education statistics. Islamabad: Government of Pakistan.

Khan, S. (1982). Compelled child labor in Punjab: A case study. Lahore: Punjab Economic Research Institute.

Massey, C. (2020). How to create a personal growth life plan to achieve your goals: Realize your dreams, live a life you love. Retrieved from https://momschoosejoy.teachable.com/p/ personal-growth-plan-course

NA. (2018). The constitution of the Islamic Republic of Pakistan [as modified up to the 31st May 2018]. Retrieved from http://na.gov.pk/uploads/documents/1549886415_632.pdf

Pasha, G., Iqbal, M., \& Farooq, S. K. (2001). Facts and Factors about the destiny of working and escaped children in Punjab (Pakistan). Pakistan Economic and Social Review, 39(1), 1-24.

Patton, M. Q. (2015). Qualitative research \& research methods (4th ed.). Thousand Oaks: Sage Publications, Inc.

Raja, C. (1983). Child labor: An explanatory study of fifty children working in auto workshops. Lahore: Department of Social Work, University of Punjab.

Ryan, R. M., \& Deci, E. L. (2009). Promoting self-determined school engagement. In K. R. Wentzel \& A. W. eld (Eds.), Handbook of motivation at school (pp. 171-195). New York: Routledge. 
Shaw, R. M., Howe, J., Beazer, J., \& Carr, T. (2019). Ethics and positionality in qualitative research with vulnerable and marginal groups. Qualitative Research, 20(3), 277-293. Retrieved from https://doi.org/10.1177/1468794119841839. doi:10.1177/1468794119841839

Stake, R. E. (2013). Multiple case study analysis. New York: Guilford Press.

UNICEF. (2020). Education: Giving every child the right to education. Retrieved from https://www.unicef.org/pakistan/education

Wiles, R. (2012). What are qualitative research ethics? London: Bloomsbury Academic.

Yin, R. K. (2018). Case study research and applications: Design and methods (6th ed.). New York: Sage publications. 